\title{
The flotation of magnetic and non-magnetic pyrrhotite from selected nickel ore deposits
}

\author{
Megan Becker $^{\mathrm{a}, *}$, Johan de Villiers ${ }^{\mathrm{b}}$, Dee Bradshaw ${ }^{\mathrm{a}, \mathrm{c}}$ \\ ${ }^{a}$ Centre for Minerals Research, University of Cape Town, South Africa \\ ${ }^{\mathrm{b}}$ Department of Materials Science $\mathcal{E}$ Metallurgical Engineering, University of Pretoria, South Africa \\ 'Julius Krutschnitt Mineral Research Centre, University of Queensland, Australia
}

\section{A R T I C L E I N F O}

\section{Article history:}

Received 18 January 2010

Accepted 4 July 2010

Available online $\mathrm{xxxx}$

\section{Keywords:}

Ore mineralogy

Sulfide ores

Oxidation

\begin{abstract}
A B S T R A C T
The non-stoichiometric sulfide mineral pyrrhotite $\left(\mathrm{Fe}_{(1-x)} S\right)$, common to many nickel ore deposits, occurs in different crystallographic forms and compositions. A series of pyrrhotite samples derived from Canada, South Africa and Botswana whose mineralogy is well characterised, were selected here in order to develop the relationship between mineralogy and flotation performance. Using both oxygen uptake and microflotation tests, the behaviour of the different pyrrhotite types was compared in terms of the effect of $\mathrm{pH}$ and collector addition. Non-magnetic pyrrhotite was less reactive in terms of its oxygen uptake and showed the best collectorless flotation recovery. Magnetic pyrrhotite was more reactive and showed poor collectorless flotation performance that could be improved with the addition of xanthate collector, but only if it was not already passivated. These differences are interpreted to be a result of pyrrhotite mineralogy. This has implications that may aid the manipulation of pyrrhotite flotation performance in processing operations.
\end{abstract}

(c) 2010 Elsevier Ltd. All rights reserved.

\section{Introduction}

Pyrrhotite $\mathrm{Fe}_{(1-x)} \mathrm{S}$ is one of the most common metal sulfide minerals occurring in both magnetic and non-magnetic forms. Pyrrhotite often occurs in association with a variety of ore deposits including $\mathrm{Ni}-\mathrm{Cu}, \mathrm{Pb}-\mathrm{Zn}$, and platinum group element (PGE). Since the principal Ni ore mineral, pentlandite, almost ubiquitously occurs coexisting with pyrrhotite, the understanding of the behaviour of pyrrhotite during flotation is of interest. For many $\mathrm{Ni}$ processing operations, pyrrhotite is rejected to the tailings in order to control circuit throughput and concentrate grade and thereby reduce excess $\mathrm{SO}_{2}$ smelter emissions (e.g. Sudbury, Wells et al., 1997). However, for some Ni processing operations, pyrrhotite recovery is targeted due to the abundant fine grained pentlandite locked in pyrrhotite (e.g. Phoenix pyrrhotite at Tati Ni Mine) or else due to the association of the platinum group elements and minerals with pyrrhotite (e.g. Merensky Reef; Penberthy and Merkle, 1999; Ballhaus and Sylvester, 2000). Therefore, the ability to manipulate pyrrhotite performance in flotation is of importance. This can be best achieved if the mineralogical characteristics of the pyrrhotite being processed are known and an understanding exists of how the flotation performance of magnetic and non-magnetic pyrrhotite types varies.

\footnotetext{
* Corresponding author. Tel.: +27 21650 3797; fax: +27 216505501

E-mail address: megan.becker@uct.ac.za (M. Becker).
}

The pyrrhotite mineral group is non-stoichiometric and has the generic formula of $\mathrm{Fe}_{(1-x)} \mathrm{S}$ where $0 \leqslant x<0.125$. Pyrrhotite is based on the nickeline (NiAs) structure and is comprised of several superstructures owing to the presence and ordering of vacancies within its structure. Numerous pyrrhotite superstructures have been recognised in the literature, but only three of them are naturally occurring at ambient conditions (Posfai et al., 2000; Fleet, 2006). This includes the stoichiometric FeS known as troilite which has on occasion, been recognised in some Ni ore deposits (e.g. Voisey's Bay; Naldrett et al., 2000). The more frequently occurring magnetic pyrrhotite is known as $4 \mathrm{C}$ pyrrhotite, has an ideal composition $\mathrm{Fe}_{7} \mathrm{~S}_{8}$ and monoclinic crystallography (Powell et al., 2004). Nonmagnetic pyrrhotite is formally described as NC pyrrhotite where $N$ is an integer between 5 and 11 (Morimoto et al. 1970). Non-magnetic NC pyrrhotite has a range of ideal compositions varying from $\mathrm{Fe}_{9} \mathrm{~S}_{10}, \mathrm{Fe}_{10} \mathrm{~S}_{11}$ to $\mathrm{Fe}_{11} \mathrm{~S}_{12}$. Although $\mathrm{NC}$ pyrrhotite is commonly known as "hexagonal pyrrhotite" due to the apparent X-ray diffraction symmetry (Posfai et al., 2000), it has recently been shown to be orthorhombic (de Villiers et al., 2009).

Pyrrhotite is a metallic conductor that is highly prone to oxidation (Rand, 1977; Belzile et al., 2004; Ekmekci et al., 2010). The effect of oxidation on flotation performance however, differs according to the degree of oxidation. Minor oxidation is known to promote pyrrhotite flotation due to the production of hydrophobic sulfur species, whereas excessive oxidation is detrimental to flotation due to the formation of hydrophilic ferric hydroxides 
(Kelebek, 1993; Kelebek et al., 2007). Although parameters such as oxygen concentration (dissolved oxygen content, relative humidity), $\mathrm{Fe}^{3+}$ concentration, $\mathrm{pH}$, temperature and galvanic effects are known to influence pyrrhotite oxidation rates (Spira and Rosenblum, 1974; Steger, 1982; Janzen et al., 2000; Almeida and Giannetti, 2003; Legrand et al., 2005b; Chirita et al., 2008), the effect of pyrrhotite mineralogy (crystal structure) on oxidation is unclear. In general, there appears to be a lack of consensus in the literature as to whether magnetic or non-magnetic pyrrhotite is more reactive towards oxidation. Magnetic monoclinic pyrrhotite however, is more frequently attributed to be the more reactive phase (Vanyukov and Razumovskaya, 1979; Yakhontova et al., 1983; Gerson and Jasieniak, 2008).

Accounts in the literature with respect to the flotation behaviour of magnetic and non-magnetic pyrrhotite are similarly somewhat contradictory. According to Iwasaki (1988), it was noted by Harada (1967; in Japanese) that samples of freshly ground monoclinic pyrrhotite were more floatable than "hexagonal" pyrrhotite, although the reverse occurred on more oxidised samples. This suggests that in an oxidising environment, the floatability of magnetic monoclinic pyrrhotite is more readily compromised due to oxidation, than non-magnetic "hexagonal" pyrrhotite. Kalahdoozan (1996) showed that synthetic "hexagonal" pyrrhotite exhibited better xanthate adsorption and flotation recovery at a higher $\mathrm{pH}$ $(\geqslant 10)$, whereas at a lower $\mathrm{pH}(7-8.5)$ monoclinic pyrrhotite was more floatable. Using pyrrhotite samples derived from the Mengzi $\mathrm{Pb}-\mathrm{Zn}$ ore deposit, He et al. (2008) also showed that monoclinic pyrrhotite was more floatable than "hexagonal" pyrrhotite. Others such as Lawson et al. (2005) and Wiese et al. (2005) have shown differences in pyrrhotite flotation performance that must surely be due to mineralogy. Lawson et al. (2005) showed a difference in pyrrhotite recovery between non-magnetic and magnetic circuits of the Sudbury ore where pyrrhotite depression was targeted. Similarly, results of batch flotation tests performed on Bushveld Merensky Reef ores by Wiese et al. (2005) have shown that the recovery of pyrrhotite from Merensky Reef ore from one location was greatly increased when copper sulfate was used as an activator during flotation, whereas for ore from another location the effect of copper sulfate addition on pyrrhotite recovery was minor. Gerson and Jasieniak (2008) also showed that the copper activation of magnetic pyrrhotite and non-magnetic pyrrhotite differed according to pyrrhotite type. It is probable that the differences between all these accounts are purely a function of the mineralogy of the pyrrhotite samples investigated.

The objective of this paper is to determine the oxygen uptake and flotation characteristics on a series of pyrrhotite samples whose mineralogy is already well characterised. In addition, it is of interest to investigate how the performance of the different pyrrhotite samples is affected by changes in $\mathrm{pH}$ and collector addition. Using such an approach, it is anticipated that the relationship between pyrrhotite mineralogy, pyrrhotite reactivity and flotation performance will be better understood.

\section{Experimental details}

Pyrrhotite samples in this study were sourced from a variety of well known sulfide nickel ore deposits within Canada, South Africa and Botswana. The mineralogy of these samples has been thoroughly characterised in Becker et al. (in press). A summary of the key mineralogical characteristics of the pyrrhotite samples used in this study is given in Table 1 . Standard optical microscopy examination of the pyrrhotite samples was performed with the use of the magnetic colloid method described in Craig and Vaughan (1981) in order to differentiate between magnetic and non-magnetic pyrrhotite. Pyrrhotite compositions were analysed on a Jeol
JXA 8100 Superprobe housed at the University of Cape Town and further details of the analysis conditions used are given in Becker et al. (in press). Quantitative determination of the proportions of the different mineral phases present in the microflotation feed samples was obtained using MLA for which the results are given in Table 2. MLA analyses were performed by Vale INCO Technical services in Toronto on a JEOL 6400 SEM fitted with two energy dispersive EDAX $\mathrm{Si}(\mathrm{Li})$ detectors with digital pulse processors. Measurements were run using the GXMAP routine so that the liberation characteristics of pyrrhotite could also be investigated (Table 3).

Experimental tests were carried out using pyrrhotite which was ground with a Sieb mill and then dry screened to the desired size fraction of 53-106 $\mu \mathrm{m}$. Pyrrhotite samples were split and then stored in a freezer until needed for the test work programme. Surface area measurements of pyrrhotite samples were obtained using the Brunauer Emmet and Teller technique on a Micrometrics Tristar 3000 unit with nitrogen adsorption to ensure that the surface area of all the pyrrhotite samples was less than $0.35 \mathrm{~m}^{2} \mathrm{~g}^{-1}$. Pyrrhotite samples were prepared for the oxygen update tests according to the procedure given in Table 4. Oxygen uptake measurements were quantified by the reactivity number (RN), using the Linde/Afrox Lab-OSCAR device. The reactivity number calculated by OSCAR is derived by fitting a graph of dissolved oxygen concentration versus time with an exponential curve, and then using the first order rate constant from this curve. Due to experimental constraints, the tests were not performed in duplicate, although previous measurements of repeatability of the reactivity number have shown $\sim 12 \%$ error (Becker, unpubl. data). Microflotation tests were conducted using the UCT microfloat cell as developed and described by Bradshaw and O'Connor (1996) using the procedure given in Table 5 . Reagent concentrations for both sets of test work were adjusted accordingly to account for the base metal sulfide content of the feed sample as given in Table 2 . The order of reagent addition and conditioning times was the same for both the oxygen uptake and microflotation tests so that the results would be directly comparable. Sodium $n$-propyl xanthate (SNPX) collector was supplied by SENMIN and Sty 504 guar from Chemquest. All microflotation tests were conducted in duplicate. Mineral concentrates were collected after 2, 5, 10 and 15 min of flotation, filtered and dried for further analysis. Although $\mathrm{Fe}, \mathrm{Ni}$ and $\mathrm{S}$ assays were obtained using atomic absorption spectroscopy and a Leco sulfur analyser, final mass recovery was determined to be the best measure of pyrrhotite recovery from the microflotation test.

\section{Results}

\subsection{Pyrrhotite mineralogy}

The pyrrhotite samples used for this study were specially selected so that the oxygen uptake and flotation performance of different naturally occurring pyrrhotite types could be investigated. Consequently, the behaviour of pure non-magnetic pyrrhotite (Sudbury CCN), pure magnetic pyrrhotite (Sudbury Gertrude West, Phoenix) and inter grown magnetic and non-magnetic pyrrhotite (Nkomati MSB) was investigated (Table 1). The mineralogy of the pyrrhotite samples prepared for oxygen uptake and microflotation tests was then analysed by MLA (Fig. 1 and Table 2) to determine the purity of the sulfide samples and investigate the liberation properties of pyrrhotite (Table 3 ). It is evident that the pyrrhotite content of all the microflotation feed samples was greater than $75 \mathrm{wt} \%$ (Fig. 1 and Table 2) and was highest for the magnetic Gertrude West pyrrhotite sample ( $85 \mathrm{wt} \%$ ). The concentration of pentlandite in the flotation feed samples varied between $6.6 \mathrm{wt} \%$ 
Table 1

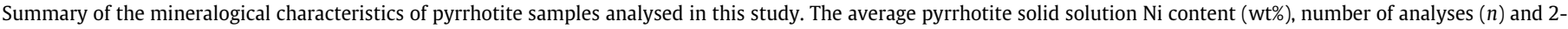
sigma standard deviation $(2 \sigma)$ is also given.

\begin{tabular}{|c|c|c|c|c|}
\hline Pyrrhotite sample & Origin & Type & Composition & $\mathrm{Ni}(w \mathrm{t} \%)$ \\
\hline Sudbury Copper Cliff North (CCN) & Canada & Non-magnetic Po & $\mathrm{Fe}_{9} \mathrm{~S}_{10}$ & $0.75(2 \sigma=0.19, n=201)$ \\
\hline Sudbury Gertrude West & Canada & Magnetic Po & $\mathrm{Fe}_{7} \mathrm{~S}_{8}$ & $0.78(2 \sigma=0.12, n=68)$ \\
\hline Tati Phoenix & Botswana & Magnetic Po & $\mathrm{Fe}_{7} \mathrm{~S}_{8}$ & $1.06(2 \sigma=0.67, n=203)$ \\
\hline Nkomati Massive Sulfide Body (MSB) & South Africa & Magnetic Po and non-magnetic Po & $\mathrm{Fe}_{7} \mathrm{~S}_{8}$ and $\mathrm{Fe}_{9} \mathrm{~S}_{10}$ & $0.43(2 \sigma=0.18, n=72)$ and $0.75(2 \sigma=0.10, n=115)$ \\
\hline
\end{tabular}

Table 2

Composition of pyrrhotite samples in wt\% used in microflotation and oxygen uptake tests as determined by MLA.

\begin{tabular}{|c|c|c|c|c|}
\hline \multirow[t]{2}{*}{ Mineral (wt\%) } & Sudbury CCN & Sudbury Gertrude West & Phoenix & Nkomati MSB \\
\hline & Non-mag Po & Mag Po & Mag Po & Mixed Po \\
\hline Pyrrhotite & 75.4 & 85.2 & 81.8 & 83.8 \\
\hline Pentlandite & 7.9 & 8.2 & 16.9 & 6.6 \\
\hline Chalcopyrite & 0.7 & 0.2 & 0.2 & 2.9 \\
\hline Pyrite & n.d. & 0.3 & 0.5 & 0.9 \\
\hline Other sulfides & n.d. & n.d. & n.d. & $<0.1$ \\
\hline Olivine & 0.4 & 0.1 & $<0.1$ & $<0.1$ \\
\hline Pyroxene & 0.4 & 0.5 & $<0.1$ & n.d. \\
\hline Amphibole & 3.4 & 0.9 & $<0.1$ & $<0.1$ \\
\hline Talc & n.d. & n.d. & n.d. & n.d. \\
\hline Serpentine & n.d. & n.d. & n.d. & n.d. \\
\hline Chlorite & 0.2 & 0.9 & $<0.1$ & $<0.1$ \\
\hline Biotite & 1.6 & 0.6 & $<0.1$ & $<0.1$ \\
\hline Plagioclase & 6.4 & 1.1 & n.d. & $<0.1$ \\
\hline Quartz & 2.3 & 0.7 & $<0.1$ & $<0.1$ \\
\hline Calcite & $<0.1$ & n.d. & n.d. & $<0.1$ \\
\hline Magnetite & 1.1 & 0.6 & 0.2 & 5.5 \\
\hline Other oxides & 0.3 & 0.3 & $<0.1$ & $<0.1$ \\
\hline Other & $<0.1$ & 0.2 & 0.1 & $<0.1$ \\
\hline Total BMS & 84.0 & 94.0 & 99.5 & 94.2 \\
\hline Total & 100 & 100 & 100 & 100 \\
\hline
\end{tabular}

n.d. denotes not detected.

Table 3

Liberation and association of pyrrhotite samples used in microflotation and oxygen uptake tests as determined by MLA.

\begin{tabular}{|c|c|c|c|c|}
\hline Pyrrhotite liberation and association & $\begin{array}{l}\text { Sudbury CCN } \\
\text { Non-mag Po }\end{array}$ & $\begin{array}{l}\text { Sudbury Gertrude West } \\
\text { Mag Po }\end{array}$ & $\begin{array}{l}\text { Phoenix } \\
\text { Mag Po }\end{array}$ & $\begin{array}{l}\text { Nkomati MSB } \\
\text { Mixed Po }\end{array}$ \\
\hline Liberated pyrrhotite & 97 & 96 & 51 & 88 \\
\hline Binaries with pentlandite & 2.0 & 2.8 & 49 & 9.3 \\
\hline Binaries with chalcopyrite & 0.4 & $<0.1$ & $<0.1$ & 1.3 \\
\hline Binaries with pyrite & $<0.1$ & 0.6 & 0.1 & $<0.1$ \\
\hline Other binaries & 0.5 & 0.2 & $<0.1$ & 0.5 \\
\hline Ternaries & $<0.1$ & 0.5 & 0.7 & 0.5 \\
\hline
\end{tabular}

Table 4

Summary of the procedure used for oxygen uptake tests.

\begin{tabular}{|c|c|c|}
\hline Activity & Conditions & $\begin{array}{l}\text { Time } \\
\text { (min) }\end{array}$ \\
\hline $\begin{array}{l}\text { Retrieval of sample } \\
\text { from freezer }\end{array}$ & $\sim 80$ g pyrrhotite sample $(53-106 \mu \mathrm{m})$ & - \\
\hline Ultrasonification & $400 \mathrm{ml}$ distilled water & 5 \\
\hline Wet screening & $\begin{array}{l}\text { Synthetic water @ desired pH, 10-2 } \\
\text { ionic strength } \mathrm{Ca}^{2+}\end{array}$ & - \\
\hline Transferral into beaker & $\begin{array}{l}\text { Sample stirring at point of depressant } \\
\text { addition }\end{array}$ & - \\
\hline Depressant addition & Sty $504 @ 10$ ppm & 5 \\
\hline Activator addition ${ }^{\mathrm{a}}$ & $\mathrm{CuSO}_{4} @ 1.6 \times 10^{-4} \mathrm{M}$ & 2 \\
\hline Collector addition $^{\mathrm{a}}$ & SNPX @ $4.0 \times 10^{-4} \mathrm{M}$ & 2 \\
\hline pH modification & $\mathrm{NaOH}$ & - \\
\hline DO measurement & - & - \\
\hline $\mathrm{O}_{2}$ introduction & $\mathrm{O}_{2}$ sparging at $1.151 \mathrm{~min}^{-1}$ & $10 \mathrm{~s}$ \\
\hline DO measurement & - & 3 \\
\hline
\end{tabular}

DO represents dissolved oxygen.

${ }^{\text {a }}$ Reagent dosages are given for a sample with $100 \%$ base metal sulfides.
Table 5

Summary of the procedure used for microflotation tests.

\begin{tabular}{|c|c|c|}
\hline Activity & Conditions & $\begin{array}{l}\text { Time } \\
(\min )\end{array}$ \\
\hline Sample weighing & 2 g pyrrhotite sample $(53-106 \mu \mathrm{m})$ & - \\
\hline Ultrasonification & $80 \mathrm{ml}$ distilled water & 5 \\
\hline Wet screening & $\begin{array}{l}\text { Synthetic water @ desired pH, 10-2 ionic } \\
\text { strength } \mathrm{Ca}^{2+}\end{array}$ & - \\
\hline $\begin{array}{l}\text { Transferral into } \\
\text { beaker }\end{array}$ & $\begin{array}{l}\text { Sample stirring at point of depressant } \\
\text { addition }\end{array}$ & - \\
\hline Depressant addition & Sty $504 @ 10$ ppm & 5 \\
\hline Activator addition ${ }^{\mathrm{a}}$ & $\mathrm{CuSO}_{4} @ 0.4 \times 10^{-5} \mathrm{M}$ & 2 \\
\hline Collector addition $^{\mathrm{a}}$ & SNPX @ $1.0 \times 10^{-5} \mathrm{M}$ & 2 \\
\hline $\mathrm{pH}$ modification & $\mathrm{NaOH}$ or $\mathrm{HNO}_{3}$ & - \\
\hline $\begin{array}{l}\text { Transferral into } \\
\text { microfloat cell }\end{array}$ & 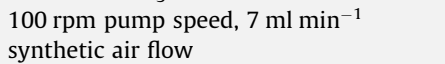 & - \\
\hline Conc. 1 collection & - & 2 \\
\hline Conc. 2 collection & - & 3 \\
\hline Conc. 3 collection & - & 5 \\
\hline Conc. 4 collection & - & 5 \\
\hline
\end{tabular}

${ }^{\text {a }}$ Reagent dosages are given for a sample with $100 \%$ base metal sulfides. 


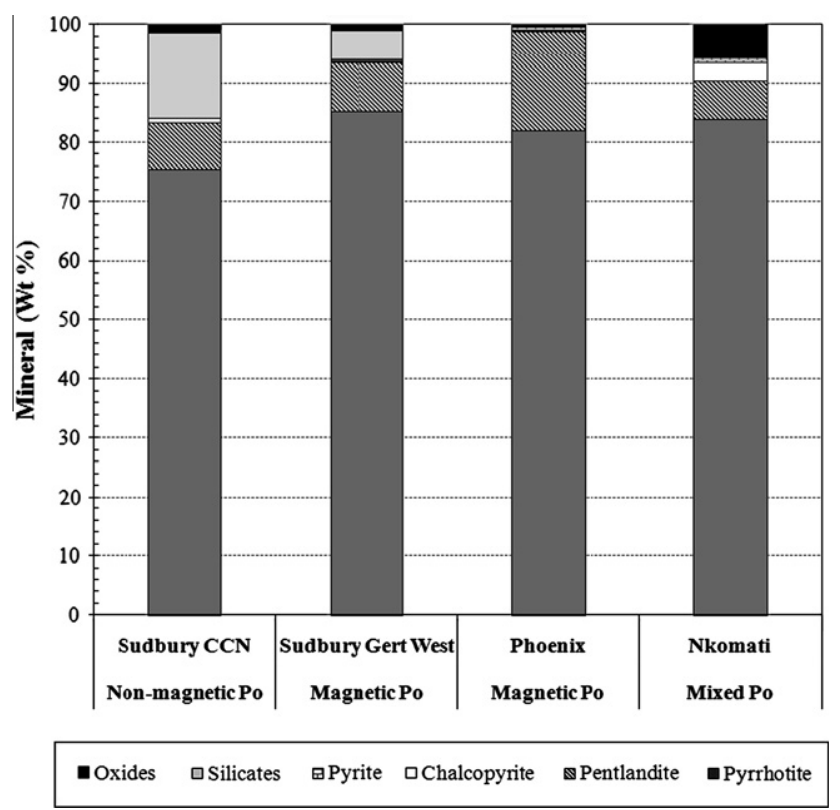

Fig. 1. Composition of pyrrhotite samples used in microflotation and oxygen uptake tests as determined by MLA.

(Nkomati) and $16.9 \mathrm{wt} \%$ (Phoenix). The proportion of chalcopyrite was very low in the flotation feed samples ( $<0.6 \mathrm{wt} \%)$, except for the Nkomati flotation feed sample which had a chalcopyrite content of $2.9 \mathrm{wt} \%$. Similarly, the pyrite content was low for all the flotation feed samples ( $<1.1 \mathrm{wt} \%)$. No pyrite was detected in the $\mathrm{CCN}$ flotation feed samples.

Pyrrhotite was over 90\% liberated in the CCN and Gertrude West microflotation feed samples (Table 3). Pyrrhotite in the Nkomati microflotation feed sample was only slightly less liberated (88\% liberated), whereas Phoenix had considerably lower pyrrhotite liberation ( $51 \%$ liberated). This was due to a significant proportion of binary particles consisting of locked flame pentlandite hosted by pyrrhotite ( $49 \%$ binaries with pentlandite for Phoenix). The amount of binary particles with chalcopyrite was very low $(<0.4 \%)$ for all the pyrrhotite samples other than the Nkomati pyrrhotite $(1.3 \%$ binaries with chalcopyrite).

\subsection{Oxygen uptake results}

Previous authors such as Spira and Rosenblum (1974), Greet and Brown (2000) and Johnson and Munro (2008) have recognised the significance of the oxygen demand of pyrrhotite rich ores in flotation. Consequently, a series of oxygen uptake tests were performed to investigate how the reactivity of the different pyrrhotite samples varies at $\mathrm{pH} 7$ and 10 (Figs. 2 and 3). It is immediately apparent that reactivity numbers obtained for the tests conducted at pH 7 are significantly lower $(<29)$ than the tests at $\mathrm{pH} 10$ due to the increase in electrochemical reaction rates at the greater $\mathrm{pH}$ (e.g. Chirita et al., 2008). Since the differences in reactivity number between the different test conditions and pyrrhotite samples are more pronounced at $\mathrm{pH} 10$, it is best to focus on these conditions to ascertain how the reactivity number varies.

The lowest reactivity numbers were obtained for the non-magnetic CCN pyrrhotite $(\mathrm{RN}=6-8)$ relative to the other pyrrhotite samples (Fig. 3). In contrast, the highest reactivity numbers were obtained for the magnetic Phoenix pyrrhotite $(R N=60-110)$. The reactivity number of the magnetic Gertrude West pyrrhotite was much lower $(\mathrm{RN}=33-36)$ than the magnetic Phoenix pyrrhotite. The reactivity numbers obtained for the mixed Nkomati pyrrhotite

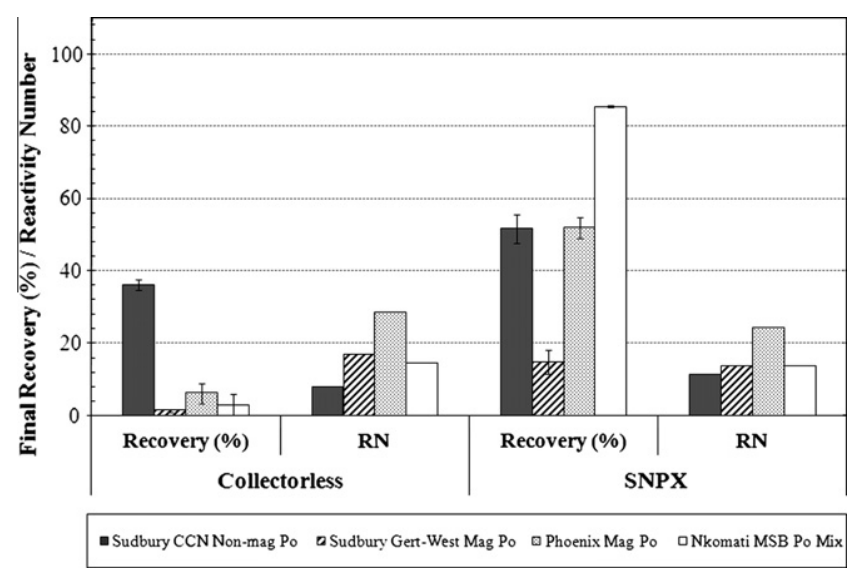

Fig. 2. Comparison of the final flotation mass recovery and reactivity number (RN) for the different pyrrhotite samples at $\mathrm{pH}$ 7. The $2 \sigma$ standard deviation is also shown for the mass recovery.

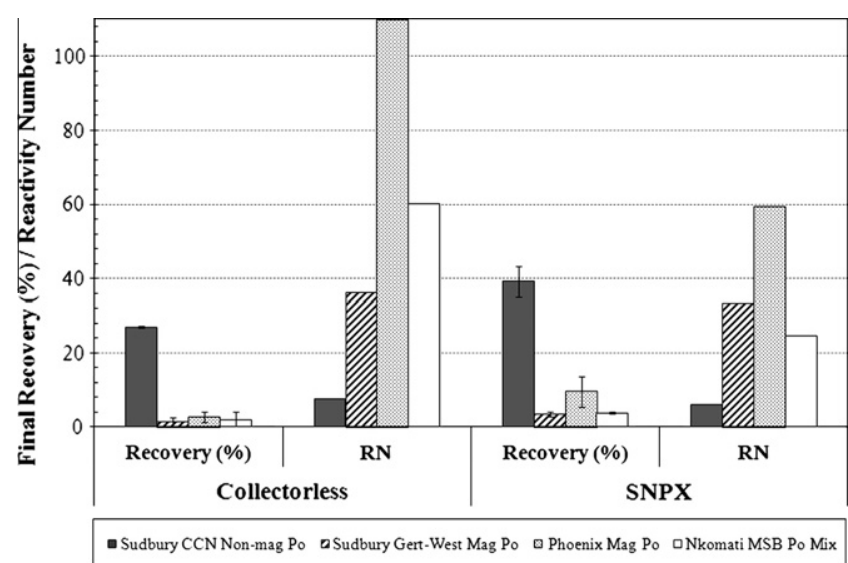

Fig. 3. Comparison of the final flotation mass recovery and reactivity number (RN) for the different pyrrhotite samples at $\mathrm{pH} 10$. The $2 \sigma$ standard deviation is also shown for the mass recovery.

$(\mathrm{RN}=25-60)$ was in between that of the non-magnetic CCN and magnetic Phoenix pyrrhotite samples. Overall, the highest reactivity numbers were obtained for the collectorless tests at $\mathrm{pH} 10$ (Fig. 3). The addition of SNPX collector caused a reduction in the reactivity number (e.g. from 110 to 60 for Phoenix magnetic pyrrhotite).

\subsection{Microflotation results}

In order to compare the differences in floatability between the pyrrhotite samples, the final mass recovery from the different test conditions is shown in Figs. 2 and 3 for pH 7 and 10, respectively. Although the feed composition of the pyrrhotite samples was variably contaminated with additional sulfide minerals such as pentlandite, their contribution to the overall mass recovery was determined not to be significant based on the analysis of the $\mathrm{Ni}$ grades for all samples other than the magnetic Gertrude West pyrrhotite.

Non-magnetic CCN pyrrhotite showed the greatest natural floatability or degree of collectorless flotation of all the samples tested at both $\mathrm{pH} 7$ (36\% recovery) and 10 (27\% recovery; Figs. 2 and 3 ). No significant differences were observed in the collectorless flotation of the other pyrrhotite samples, other than the recovery was slightly lower at $\mathrm{pH} 10(<10 \%$ recovery) than $\mathrm{pH} 7(<11 \%$ recovery). The addition of SNPX collector at $\mathrm{pH} 7$ served to improve 
the floatability of all of the pyrrhotite samples at $\mathrm{pH} 7$ other than Gertrude West. At pH 10, the addition of collector only caused an improvement in the floatability of the CCN pyrrhotite.

\section{Discussion}

\subsection{Relationship between reactivity and flotation}

In order to determine the effect of mineralogy on the reactivity and flotation of pyrrhotite, the nature of the relationship between reactivity and flotation first needs to be established. In order to do so, some understanding of the electrochemical reactions active on the surface of pyrrhotite is required. In the electrochemical study of Ekmekci et al. (2010) on these particular pyrrhotite samples, three anodic reactions were identified in cyclic voltammetry studies:

$\mathrm{Fe}_{(1-x)} \mathrm{S}+3 y \mathrm{OH}^{-}=\mathrm{Fe}_{(1-(x+y)} \mathrm{S}+y \mathrm{Fe}(\mathrm{OH})_{3}+3 y \mathrm{e}^{-}$

$\mathrm{FeS}_{1.13}+3 \mathrm{OH}^{-}=\mathrm{Fe}(\mathrm{OH})_{3}+1.13 \mathrm{~S}+3 \mathrm{e}^{-}$

$\mathrm{Fe}(\mathrm{OH})_{2}+\mathrm{H}_{2} \mathrm{O}=\mathrm{Fe}(\mathrm{OH})_{3}+\mathrm{H}^{+}+\mathrm{e}^{-}$

Reaction (I) corresponds to the initial oxidation of pyrrhotite and the production of a ferric hydroxide and a sulfur rich sublayer. Reaction II corresponds to the further oxidation of pyrrhotite and the production of elemental sulfur. Reaction III corresponds to the further oxidation of ferrous hydroxide to ferric hydroxide (Hamilton and Woods, 1981; Buswell and Nicol, 2002).

In order to promote the collectorless flotation of pyrrhotite, some mild oxidation is required. A variety of species varying between elemental sulfur, polysulfides, metal deficient sulfides to a stable $\mathrm{Fe}(\mathrm{OH}) \mathrm{S}_{2}$ intermediate species have all been proposed to provide the necessary hydrophobicity for the collectorless flotation of pyrrhotite (Hamilton and Woods, 1981; Heyes and Trahar, 1984; Hodgson and Agar, 1984; Buckley and Woods, 1985; Legrand et al., 2005a). However, extensive oxidation is well known to be detrimental to the flotation performance of pyrrhotite due to the formation of hydrophilic ferric hydroxides species (e.g. Rao and Finch, 1991; Kelebek, 1993). Although ferric hydroxide species were not actively identified on the surface of pyrrhotite during the oxygen uptake and micoflotation tests in this study, their presence is inferred as the cause of poor pyrrhotite flotation.

From the results illustrated in Figs. 2 and 3, it is clear that under conditions where pyrrhotite has a high reactivity for oxidation, poor flotation recovery is observed (e.g. Phoenix magnetic pyrrhotite). Pyrrhotite samples with low reactivity numbers can either show good flotation performance (CCN) due to their less reactive nature or alternatively poor flotation performance (Gertrude West) if they are already oxidised. On this basis, the effects of $\mathrm{pH}$, collector addition and pyrrhotite mineralogy are discussed.

\subsection{Effect of $p H$}

For all of the pyrrhotite samples examined, there was an increase in reactivity number from $\mathrm{pH} 7$ to 10 due to the increase in reaction rates at the more alkaline $\mathrm{pH}$ (Figs. 2 and 3 ). This is consistent with other studies that have shown an increase in the oxidation rate constant with increasing $\mathrm{pH}$ (Janzen, 1996; Chirita et al. 2008). Due to the increase in $\mathrm{OH}^{-}$concentration at $\mathrm{pH} 10$, increased oxidation rates and stability of the hydrophilic ferric hydroxide species, the floatability of pyrrhotite was decreased for all of the samples and investigated. The reason for the reduction in pyrrhotite flotation with increasing $\mathrm{pH}$ is described by the Barsky relationship where $\left[\mathrm{X}^{-}\right] /\left[\mathrm{OH}^{-}\right]=\mathrm{K}$ (Kelebek et al., 2007) in that the presence of excess hydroxide anions interferes with xanthate adsorption.

\subsection{Effect of collector addition}

In general, the addition of collector caused a decrease in the reactivity numbers obtained in the oxygen uptake studies (Figs. 2 and 3). This can be attributed to the adsorption of the collector on the pyrrhotite surface that retarded further pyrrhotite oxidation. Spira and Rosenblum (1974) also noted a decrease in oxygen demand of pyrrhotite in their study that was argued to restrict the access of oxygen to the pyrrhotite surface, although this was due to $\mathrm{NaCN}$ addition and not xanthate as in this study. Although a decrease in pyrrhotite reactivity occurred with collector addition, the floatability of all the pyrrhotite samples improved with the addition of xanthate. This is attributed to the adsorption of collector on pyrrhotite, followed by oxidation and formation of the dixanthogen species $\left(\mathrm{PoX}_{2}\right)$ which is known to render pyrrhotite its hydrophobicity (Allison et al., 1972; Fornasiero et al., 1995; Bozkurt et al., 1998). Kelebek (1993) suggested that mild oxidation of the pyrrhotite surface promoted the amount of surface sites available for xanthate adsorption, the production of elemental sulfur and the oxidation of xanthate to dixanthogen. Extensive oxidation however, would have shifted the balance so that the layer of hydrophilic ferric hydroxides covering the surface of the pyrrhotite would have been too thick to allow for sufficient xanthate adsorption. Therefore differences in the floatability of the different pyrrhotite samples with collector addition are interpreted to be influenced by the reactivity of pyrrhotite for oxidation.

\subsection{Effect of mineralogy}

The results illustrated in Figs. 2 and 3 show that some sort of relationship exists between pyrrhotite mineralogy, reactivity and flotation performance. Therefore it is necessary to determine what the influence of pyrrhotite mineralogy is on these results. In terms of the behaviour of magnetic pyrrhotite, it is evident that the reactivity varies between the different samples. The most reactive pyrrhotite sample in this study was the magnetic Phoenix pyrrhotite, whereas the "least" reactive pyrrhotite was the magnetic Gertrude West pyrrhotite. Based on the very poor flotation performance of the Gertrude West pyrrhotite it is proposed that this pyrrhotite sample was so reactive that it was already passivated at the time of the reactivity number measurement. In contrast, the non-magnetic CCN pyrrhotite was also relatively unreactive towards oxidation and yet showed good flotation performance. This indicates that the amount of oxidation it experienced was just sufficient to promote the flotation of pyrrhotite. The reactivity of the mixed Nkomati pyrrhotite was in between that of the non-magnetic $\mathrm{CCN}$ and magnetic Phoenix pyrrhotite, and indicates that the reactivity of inter grown magnetic and non-magnetic pyrrhotite is most likely a combination of that of its end members. These results show that pyrrhotite behaviour cannot simply be explained by whether it is magnetic or non-magnetic, and therefore several mineralogical factors are reviewed here. Ultimately, a combination of these factors is considered to control pyrrhotite behaviour.

\subsection{Crystallography}

During the oxidation of pyrrhotite, electrons from within the crystal lattice move to the pyrrhotite surface to facilitate oxygen reduction. Pratt et al. (1994) proposed a mechanism for pyrrhotite oxidation by which the only movement of species during the reaction was the transfer of electrons from the crystal lattice and the diffusion of iron towards the surface ferric oxyhyroxide layer. Pratt et al. (1994) argued that the most reactive sites for oxygen reduction were associated with the ferric iron-sulfur bonds and the vacancies in the pyrrhotite crystal lattice. The presence of vacancies would therefore facilitate electron transfer as well as 
the diffusion of iron through the crystal lattice to the surface, thereby assisting the oxidation reaction. Since the magnetic pyrrhotite structure has more vacancies or hole type conductivity relative to non-magnetic pyrrhotite, it is hypothesised that that the greater abundance of vacancies accelerates the oxidation process for magnetic pyrrhotite relative to non-magnetic pyrrhotite. For the samples examined in this study, this would theoretically relate to one vacancy for every eight Fe sites for the magnetic $\mathrm{Fe}_{7} \mathrm{~S}_{8}$ pyrrhotite samples, and one in ten Fe sites would be vacant for the non-magnetic $\mathrm{Fe}_{9} \mathrm{~S}_{10}$ pyrrhotite.

The presence of vacancies and their role in facilitating more rapid oxidation and greater reactivity for magnetic pyrrhotite relative to non-magnetic pyrrhotite is in agreement with the results of the oxidation studies of Gerson and Jasieniak (2008) and Lehmann et al. (2000). Gerson and Jasieniak (2008) observed more rapid oxidation of monoclinic pyrrhotite relative to "hexagonal" pyrrhotite with ToF-SIMS. Lehmann et al. (2000) measured both larger rate constants and lower activation energy for the oxidation of monoclinic relative to "hexagonal" pyrrhotite. Janzen (1996) however, found no correlation between oxidation rate and crystallography but since the experiments of Janzen (1996) were performed on pyrrhotite samples derived from multiple provenances, it is likely that the dataset was not sensitive enough in order to isolate these differences. The oxygen demand tests of Spira and Rosenblum (1974) also showed a greater oxygen demand for non-magnetic pyrrhotite relative to magnetic Noranda pyrrhotite. However, the oxygen uptake tests from this study have demonstrated that if the magnetic pyrrhotite is already passivated it can appear to be relatively unreactive.

The microflotation results are similarly in agreement with the account of Iwasaki (1988) from (Harada, 1967; in Japanese), that "hexagonal" pyrrhotite was more floatable than monoclinic pyrrhotite when the sample was oxidised. The results from this study are in partial agreement with Kalahdoozan (1996), where it was found that "hexagonal" pyrrhotite was more floatable than monoclinic pyrrhotite at $\mathrm{pH} 10$. At $\mathrm{pH} 7$, however, monoclinic pyrrhotite was more floatable. In the study of He et al. (2008), it was shown that monoclinic pyrrhotite was more floatable through a range of $\mathrm{pH}$ conditions in the presence of xanthate collector. However, since $\mathrm{He}$ et al. (2008) used pyrrhotite derived from $\mathrm{Pb}-\mathrm{Zn}$ ores in their flotation experiments, the influence of pyrrhotite origin may account for the differences in flotation performance.

\subsection{Mineral chemistry}

Both $\mathrm{O}_{2}$ and $\mathrm{Fe}^{3+}$ are known to be oxidising agents of pyrrhotite (Hamilton and Woods, 1981; Janzen, 1996; Belzile et al., 2004) and so the presence of both these species within the pyrrhotite structure needs to be evaluated. $\mathrm{Fe}^{3+}$ was noted by Janzen (1996) to be a much stronger oxidising agent than $\mathrm{O}_{2}$. The presence of both $\mathrm{Fe}^{2+}$ and $\mathrm{Fe}^{3+}$ has been argued to be present in the pyrrhotite structure in order to maintain charge balance (Bertaut, 1953; Pratt et al., 1994; Mikhlin and Tomashevich, 2005). Therefore, magnetic pyrrhotite of formula $\mathrm{Fe}_{2}^{3+} \mathrm{Fe}_{5}^{2+} \mathrm{S}_{8}^{2-}\left(\mathrm{Fe}_{7} \mathrm{~S}_{8}\right)$ contains proportionally more $\mathrm{Fe}^{3+}$ in its structure than non-magnetic pyrrhotite of formula $\mathrm{Fe}_{2}^{3+} \mathrm{Fe}_{7}^{2+} \mathrm{S}_{10}^{2-}\left(\mathrm{Fe}_{9} \mathrm{~S}_{10}\right)$. Consequently, it could be expected that magnetic pyrrhotite is more prone to oxidation than non-magnetic pyrrhotite because of the greater proportion of $\mathrm{Fe}^{3+}$ acting as an oxidising agent within its structure.

The presence of $\mathrm{O}_{2}$ associated with pyrrhotite should also be considered as a potential oxidising agent. Results of the mineralogical characterisation studies of these pyrrhotite samples (Becker et al., in press) provide more than sufficient evidence to suggest that oxygen in the form of magnetite is often associated with pyrrhotite. On the basis of this observation, it can be concluded that oxygen is present during the crystallisation and formation of pyr- rhotite (e.g. Kullerud, 1957). Therefore, it is not implausible that some minor proportion of oxygen could have been accommodated within the pyrrhotite crystal structure. The results of the nuclear microprobe analyses of Graham and Mc Kenzie (1987) showed the presence of detectable amounts of oxygen of $\sim 0.05 \mathrm{wt} \%$ within both monoclinic and "hexagonal" pyrrhotite. The presence of trace amounts of dissolved oxygen in the pyrrhotite crystal structure is proposed as another potential mechanism causing differences in pyrrhotite reactivity. This is an area that needs further investigation, but may account for differences in reactivity between magnetic pyrrhotite derived from different ore deposits (Gertrude West versus Phoenix).

The mineralogical characterisation also showed that the solid solution Ni content in pyrrhotite was variable (Table 1 ). In the study of Kwong (1993), a semi-quantitative correlation was found between $\mathrm{Ni}$, Co content and oxidation rate for monoclinic pyrrhotite. Pyrrhotite samples enriched in $\mathrm{Ni}$ and $\mathrm{Co}$ were found to oxidise slightly slower, most likely due to the positive effective charge as a result of the donor defects caused by the substitution of Co and Ni for Fe (Kwong, 1993). The implication of a positive effective charge within the vicinity of Ni substitution sites would be to retard the movement of electrons, thereby inhibiting the oxidation process. This is another additional mechanism to potentially account for the difference in reactivity observed between magnetic pyrrhotite samples derived from different ore bodies (Gertrude West versus Phoenix).

\subsection{Mineral association}

In the samples investigated in this study, the Nkomati pyrrhotite was the only pyrrhotite sample containing inter grown magnetic and non-magnetic pyrrhotite. Due to the conductive or semi-conductive nature of the sulfide minerals, galvanic interactions may occur when two sulfide minerals come into contact with one another. The presence of a galvanic interaction could cause more severe oxidation than expected for the anodic mineral compared to that expected if the mineral occurred on its own. Middlings or locked particles are known to suffer from galvanic effects more so than liberated particles (Almeida and Giannetti, 2003). Galvanic interaction between two minerals is dependent on the difference in rest potential of the two sulfide minerals and only when the difference is sufficiently high enough between the anodic and cathodic minerals, will there be a galvanic current. Even though differences have been noted here between the reactivity of magnetic and non-magnetic pyrrhotite, these are by no means comparable to the scale of the differences that are experienced during the operation of a true galvanic cell (Ekmekci and Demirel, 1997). Therefore, it is considered unlikely that galvanic interactions are effective between inter grown magnetic and non-magnetic pyrrhotite.

The association of pyrrhotite with other minerals is important however, especially as binary particles with pentlandite for the Nkomati and Phoenix samples (Table 3). This is not surprising given the derivation of the samples from active Ni mines. Since pentlandite is more noble than pyrrhotite (Rand, 1977), a galvanic interaction between the two minerals is likely, especially if significant pentlandite occurs and the minerals are in close contact with one another (e.g. Cheng and Iwasaki, 1992; Nakazawa and Iwasaki, 1995; Ekmekci and Demirel, 1997). Only the Phoenix magnetic pyrrhotite sample contained significant quantities of pentlandite (17 wt\%, Table 1) due to the abundance of locked flame pentlandite represented as binary pyrrhotite particles with pentlandite $(49 \%$, Table 3). Therefore, a galvanic interaction is expected to result in increased reactivity of the Phoenix pyrrhotite. Based on the interpretation that the Gertrude West pyrrhotite (that was $96 \%$ liberated) is so reactive that it was already passivated at the time of 
the oxygen uptake experiment (i.e. that it is even more reactive than the Phoenix pyrrhotite; Ekmekci et al., 2010), there is no conclusive evidence that the reactivity of the Phoenix pyrrhotite was increased due to galvanic effects.

The presence of locked pentlandite in pyrrhotite, is however, thought to have an active influence on the flotation performance of those pyrrhotite samples where binary particles with pentlandite are present (Phoenix, Nkomati; Table 3). Various studies have described how the flotation rate of pyrrhotite is slower than pentlandite (e.g. Buswell and Nicol, 2002; Miller et al., 2005). Therefore, the flotation performance of pyrrhotite may be improved due to the presence of unliberated pentlandite present in composite pyrrhotite-pentlandite particles. Chalcopyrite is also known for its good floatability, and therefore the association of pyrrhotite with chalcopyrite needs to be considered. However, since the proportion of binary pyrrhotite particles with chalcopyrite is so small $(<1.3 \%$, Table 3), the flotation of composite pyrrhotite-chalcopyrite binary particles is not considered to be a controlling factor for the samples investigated in this study.

Another mechanism related to the presence of pentlandite associated with pyrrhotite is that caused by the release of $\mathrm{Ni}$ ions from pentlandite and inadvertent activation of pyrrhotite. The inadvertent activation of pyrrhotite from nickel ions has previously been described for the Sudbury ores by Yoon et al. (1995) and Xu and Wilson (2000). It is possible that the flotation performance of those pyrrhotite samples containing significant locked flame pentlandite would be improved due to inadvertent activation by $\mathrm{Ni}$ ions associated with the flame pentlandite.

\section{Conclusions}

In this study, a series of non-magnetic and magnetic pyrrhotite samples derived from different $\mathrm{Ni}$ ores were used to investigate the relationship between pyrrhotite mineralogy, reactivity and flotation performance. The results show that oxidation of reactive pyrrhotite results in poor pyrrhotite floatability due to the formation of hydrophilic ferric hydroxides. Non-magnetic Sudbury CCN pyrrhotite was the least reactive to oxidation of the pyrrhotite samples investigated and showed the best flotation performance. The flotation performance of magnetic pyrrhotite however, was dependent upon the reactivity of the pyrrhotite sample. Magnetic Sudbury Gertrude West was interpreted to be so reactive that the surfaces were already oxidised and passivated at the time of the reactivity number measurement and which resulted in poor flotation performance. The magnetic Phoenix pyrrhotite was not as reactive towards oxidation, and therefore its flotation was good. The reactivity of the Nkomati pyrrhotite was in between non-magnetic Sudbury CCN and magnetic Phoenix due to the combined contribution of inter grown magnetic and non-magnetic pyrrhotite.

The results of this study show that pyrrhotite behaviour cannot simply be explained by a single mineralogical factor, but that it is a combination of mineralogical characteristics governing its reactivity and flotation performance. These key mineralogical factors are the crystallography (number of vacancies), mineral chemistry (ferric iron and nickel content) and mineral association (composite particles). The association of pyrrhotite with pentlandite is important since pyrrhotite flotation can be positively influenced by the flotation of composite particles comprising abundant locked flame pentlandite.

\section{Acknowledgements}

The authors would like to acknowledge Impala Platinum, Norilsk Nickel, VALE Inco and Senmin for supporting this research in terms of funding and supplying pyrrhotite samples for analysis. Thanks to Fred Ford from Vale INCO in Toronto for the MLA analyses and to Martin Verster for his interest and guidance with the reactivity number measurements.

\section{References}

Allison, S.A., Goold, L.A., Nicol, M.J., Granville, A., 1972. A determination of the products of reaction between various sulfide minerals and aqueous xanthate solution, and a correlation of the products with electrode rest potentials. Metallurgical Transactions 3, 2513-2618.

Almeida, C.M.V.B., Giannetti, B.F., 2003. The electrochemical behaviour of pyritepyrrhotite mixtures. Journal of Electroanalytical Chemistry 553, 27-34.

Ballhaus, C., Sylvester, P.J., 2000. Noble metal enrichment processes in the Merensky Reef, Bushveld complex. Journal of Petrology 41, 545-561.

Becker, M., de Villiers, J.P.R., Bradshaw, D.J., in press. The mineralogy and crystallography of pyrrhotite from selected nickel and PGE ore deposits. Economic Geology.

Bertaut, P.E.F., 1953. Contribution a l'Etude des Structures Lacunaires: La pyrrhotine. Acta Crystallographica 6, 557-561.

Belzile, N., Chen, Y.-W., Cai, M.-F., Li, Y., 2004. A review of pyrrhotite oxidation. Journal of Geochemical Exploration 84, 65-76.

Bozkurt, V., Xu, Z., Finch, J.A., 1998. Pentlandite/pyrrhotite interaction and xanthate adsorption. International Journal of Mineral Processing 52, 203-214.

Bradshaw, D.J., O'Connor, C.T., 1996. Measurement of the sub-process of bubble loading in flotation. Minerals Engineering 9, 443-448.

Buckley, A.N., Woods, R., 1985. X-ray photoelectron spectroscopy of oxidized pyrrhotite surfaces. 1. Exposure in air. Applications of Surface Science 22 (23), 280-287.

Buswell, A.M., Nicol, M.J., 2002. Some aspects of the electrochemistry of the flotation of pyrrhotite. Journal of Applied Electrochemistry 32, 1321-1329.

Cheng, X., Iwasaki, I., 1992. Effect of chalcopyrite and pyrrhotite interaction on flotation separation. Minerals and Metallurgical Processing 9, 73-79.

Chirita, P., Descostes, M., Schlegel, M.L., 2008. Oxidation of FeS by oxygen-bearing acidic solutions. Journal of Colloid and Interface Science 321, 84-95.

Craig, J.R., Vaughan, D.J., 1981. Ore Microscopy and Ore Petrography. John Wiley and Sons, New York.

de Villiers, J.P.R., Liles, D., Becker, M., 2009. The crystal structure of a naturally occurring $5 \mathrm{C}$ pyrrhotite from Sudbury, its chemistry and vacancy distribution. American Mineralogist 94, 1405-1410.

Ekmekci, Z., Becker, M., Bagki Tekes, E., Bradshaw, D.J., 2010. The relationship between the electrochemical, mineralogical and flotation characteristics of pyrrhotite samples from different $\mathrm{Ni}$ ores. Journal of Electroanalytical Chemistry, doi:10.1016/j.jelechem.2010.06.011

Ekmekci, Z., Demirel, H., 1997. Effects of galvanic interaction on collectorless flotation behaviour of chalcopyrite and pyrite. International Journal of Mineral Processing 52, 31-48.

Fleet, M.E., 2006. Phase equilibria at high temperatures. In: Vaughan, D.J. (Ed.), Sulfide Mineralogy and Geochemistry. MSA, Washington DC, USA, pp. 365-419.

Fornasiero, D., Montalti, M., Ralston, J., 1995. Kinetics of adsorption of ethyl xanthate on pyrrhotite: in-situ UV and infrared spectroscopic studies. Journal of Colloid and Interface Science 172, 467-478.

Gerson, A., Jasieniak, M., 2008. The effect of surface oxidation on the $\mathrm{Cu}$ activation of pentlandite and pyrrhotite. In: 24th International Mineral Processing Congress. Science Press, Beijing, pp. 1054-1063

Graham, J., Mc Kenzie, A.D., 1987. Oxygen in Pyrrhotite: 2. Determination of oxygen in natural pyrrhotites. American Mineralogist 72, 605-609.

Greet, C.J., Brown, S., 2000. Oxygen demand testing - a new laboratory procedure. In: 7th Mill Operators' Conference. Kalgoorlie, pp. 189-195.

Hamilton, I.C., Woods, R., 1981. An investigation of surface oxidation of pyrite and pyrrhotite by linear potential sweep voltammetry. Journal of Electroanalytical Chemistry 118, 327-343.

Harada, T., 1967. Variation in floatability of pyrrhotites. Nippon Kogyo Kaishi (Journal of the Mining and Metallurgical Institute of Japan) 83, 656-660.

He, M.F., Qin, W.Q., Liz, W.Z., Chen, Y.J., Lai, C.H., 2008. Research on flotation performances of polymorphic pyrrhotite. In: 24th International Mineral Processing Congress. Science Press, Beijing, pp. 1153-1160.

Heyes, G.W., Trahar, W.J., 1984. The flotation of pyrite and pyrrhotite in the absence of conventional collectors. In: Richardson, P.R., Srinivasan, S.S., Woods, R. (Eds.), Electrochemistry in Mineral and Metal Processing. ECS, Pennington, NJ, USA, pp. 219-232.

Hodgson, M., Agar, G.E., 1984. An electrochemical investigation into the natural flotability of pyrrhotite. In: Richardson, P.R., Srinivasan, S.S., Woods, R. (Eds.), Electrochemistry in Mineral and Metal Processing. ECS, Pennington, NJ, USA, pp. 185-201.

Iwasaki, I., 1988. Flotation behaviour of pyrrhotite in the processing of coppernickel ores. In: Tyroler, G.P., Landolt, C.A. (Eds.), Extractive Metallurgy of Nickel and Cobalt. TMS, Warrendale, PA, USA, pp. 272-292.

Janzen, M.P., 1996. Role of Ferric Iron, Trace Metal Content, and Crystal Structure on Pyrrhotite Oxidation. MSc Thesis, University of Waterloo.

Janzen, M.P., Nicholson, R.V., Scharer, J.M., 2000. Pyrrhotite reaction kinetics: reaction rates for oxidation by oxygen, ferric iron, and for non-oxidation dissolution. Geochimica et Cosmochimica Acta 64, 1511-1522. 
Johnson, N.W., Munro, P.D., 2008. Methods for assigning domains in the primary sulfide zone of a sulfide orebody. In: 9th International Congress for Applied Mineralogy. AusIMM, Brisbane, pp. 597-603.

Kalahdoozan, M., 1996. Adsorption and Flotation Characteristics of Hexagonal and Monoclinic Pyrrhotite. PhD Thesis, Queens University.

Kelebek, S., 1993. The Effect of Oxidation on the Flotation Behaviour of NickelCopper Ores. XVIII Mineral Processing Congress. Sydney. pp. 999-1005.

Kelebek, S., Nanthakumar, B., Katsabanis, P.D., 2007. Oxidation of complex Ni-Cu sulphide ores and its implication for flotation practice. Canadian Metallurgical Quarterly 46, 279-284.

Kullerud, G., 1957. Phase relations in the Fe-S-O system. Carnegie Institute of Washington Year Book 56, 198-200.

Kwong, Y.T.J., 1993. Prediction and Prevention of Acid Rock Drainage from a Geological and Mineralogical Perspective. NRCan, Ottawa.

Lawson, V, Kerr, A.N., Shields, Y., Wells, P.F., Xu, M., Dai, Z. 2005. Improving pentlandite pyrrhotite separation at INCO's Clarabelle Mill. In: Centenary of Flotation Symposium. AusIMM, Brisbane, pp. 875-885.

Legrand, D.L., Bancroft, G.M., Nesbitt, H.W., 2005a. Oxidation/alteration of pentlandite and pyrrhotite surfaces at $\mathrm{pH}$ 9.3: part I. Assignment of XPS spectra and chemical trends. American Mineralogist 90, 1042-1054.

Legrand, D.L., Bancroft, G.M., Nesbitt, H.W., 2005b. Oxidation of pentlandite and pyrrhotite surfaces at $\mathrm{pH}$ 9.3: part 2. Effect of xanthates and dissolved oxygen. American Mineralogist 90, 1055-1061.

Lehmann, M.N., Kaur, P., Pennifold, R.M., Dunn, J.G., 2000. A comparative study of the dissolution of hexagonal and monoclinic pyrrhotites in cyanide solution. Hydrometallurgy 55, 255-273.

Mikhlin, Y., Tomashevich, Y., 2005. Pristine and reacted surfaces of pyrrhotite and arsenopyrite as studied by X-ray absorption near-edge structure spectroscopy. Physics and Chemistry of Minerals 32, 19-27.

Miller, J.A., Li, C., Davidtz, J.C., Vos, F., 2005. A review of pyrrhotite flotation chemistry in the processing of PGM ores. Minerals Engineering 18, 855-865.

Morimoto, N., Nakazawa, H., Nishiguchi, K., Tokonami, M., 1970. Pyrrhotites: Stoichiometric compounds with composition $\mathrm{Fe}_{\mathrm{n}-1} \mathrm{~S}_{\mathrm{n}}(n>8)$. Science 168, 964966.

Naldrett, A.J., Singh, J., Krstic, S., Li, C.S., 2000. The mineralogy of the Voisey's Bay $\mathrm{Ni}-\mathrm{Cu}-\mathrm{Co}$ deposit, northern Labrador, Canada: Influence of oxidation state on textures and mineral compositions. Economic Geology 95, 889-900.

Nakazawa, H., Iwasaki, I., 1995. Effect of pyrite-pyrrhotite contact on their floatabilities. Minerals and Metallurgical Processing 2, 206-211.
Penberthy, C.J., Merkle, R.K.W., 1999. Lateral variations in the platinum-group element content and mineralogy of the UG2 Chromitite layer, Bushveld Complex. South African Journal of Geology 102, 240-250.

Posfai, M., Sharp, T.G., Kontny, A., 2000. Pyrrhotite varieties from the $9.1 \mathrm{~km}$ deep borehole of the KTB project. American Mineralogist 85, 1406-1415.

Powell, A.V., Vaqueiro, P., Knight, K.S., Chapon, L.C., Sanchez, R.D., 2004. Structure and magnetism in synthetic pyrrhotite $\mathrm{Fe}_{7} \mathrm{~S}_{8}$ : a powder neutron-diffraction study. Physical Review B 70, 014415-1-014415-12.

Pratt, A.R., Muir, I.J., Nesbitt, H.W., 1994. X-ray photoelectron and Auger electron spectroscopic studies of pyrrhotite and mechanism of air oxidation. Geochimica et Cosmochimica Acta 58, 827-841.

Rand, D.A.J., 1977. Oxygen reduction of sulphide minerals: Part III. Comparison of activities of various copper, iron, lead and nickel mineral electrodes. Journal of Electroanalytical Chemistry 83, 19-32.

Rao, S.R., Finch, J.A., 1991. Adsorption of amyl xanthate at pyrrhotite in the presence of nitrogen and implications in flotation. Canadian Metallurgical Quarterly 30, $1-6$.

Spira, P, Rosenblum, F., 1974. The oxygen demand of flotation pulps. In: 6th Annual Meeting of the Canadian Mineral Processors. CIM, Ottawa, pp. 74-106

Steger, H.F., 1982. Oxidation of sulfide minerals VII. Effect of temperature and relative humidity on the oxidation of pyrrhotite. Chemical Geology 35, 281295.

Vanyukov, A.V., Razumovskaya, N.N., 1979. Hydrothermal oxidation of pyrrhotites. Izvestiya Visshih Uchebnih Zavedeniy - Tsvetniye Metalli 6, 605-610.

Wells, P.F., Kelebek, S., Burrows, M.J., Suarez, D.F., 1997. Pyrrhotite rejection at Falconbridge's Strathcona Mill. In: Finch, J.A., Rao, S.R., Holubec, I. (Eds.) Processing of Complex Ores: Mineral Processing and the Environment. Montreal, CIM, pp. 51-62.

Wiese, J.G., Harris, P.J., Bradshaw, D.J., 2005. The influence of the reagent suite on the flotation of ores from the Merensky Reef. Minerals Engineering 18, 189-198.

$\mathrm{Xu}, \mathrm{M}$., Wilson, S., 2000. Investigation of seasonal metallurgical shift at INCO's Clarabelle Mill. Minerals Engineering 13, 1207-1218.

Yakhontova, L.K., Nesterovich, L.G. Grudev, A.P., 1983. New data on natura oxidation of pyrrhotite. Vestnik Moskovskogo Universiteta Geologiya (Newsletter of The Moscow University of Geology) 38, 41-44.

Yoon, R.-H., Basilio, C.I., Marticorena, M.A., Kerr, A.N., Stratton-Crawley, R., 1995. A study of the pyrrhotite depression mechanism by diethylenetriamine. Minerals Engineering 8, 807-816. 